FACTA UNIVERSITATIS

Series: Physical Education and Sport, Vol. 16, No 2, 2018, pp. 493 - 501

https://doi.org/10.22190/FUPES171104044P

Professional article

\title{
BRANKO ČUBRILOVIĆ AND SERBIAN SOKOLISM UDC 796.03
}

\author{
Kristina Pantelić-Babić ${ }^{1}$, Petar Pavlović ${ }^{1}$, Nenad Živanović ${ }^{2}$ \\ ${ }^{1}$ Faculty of Physical Education and Sports, University of Banja Luka, \\ Republic of Srpska, Bosnia and Herzegovina \\ ${ }^{2}$ FIEP Europe-Section for History of Sports, Niš, Serbia
}

\begin{abstract}
At the end of the $19^{\text {th }}$ century in the Czech Republic a new way of physical exercise entitled the "Sokol" or "Tyršs" system appeared. It spread to all the countries where Slavs lived and thus arrived among the Serbs who lived on the territory of Bosnia and Herzegovina. A group of Serbs from Foča in 1893 tried to establish the Serbian Soko society but the Austro-Hungarian authorities did not allow it. The first Serbian gymnastic society on the territory of Bosnia and Herzegovina called "Obilić" was founded in 1904 in Mostar. Many educated people of that time participated in the work of the Soko organizations, among them the medical doctor Branko Cubrilović. The main subject of this paper is Branko Čubrilovic and his connections with Serbian Sokolism and the aim is to highlight his role in the development of Serbian Sokolism, primarily in the areas of Bosnia and Herzegovina, as well as in other areas where Serbs lived. The authors used a historical method.
\end{abstract}

Key words: soko societies, sokols, students, members

\section{INTRODUCTION}

During the $19^{\text {th }}$ century in Europe, several ways (systems) of physical exercise appeared: German, French, Swedish, English, and in the second half of the century the Sokol (Tyrš) system appeared in the Czech Lands. This type of physical exercise originated in 1862, when Miroslav Tyrš founded the Prague "Prague Gymnastics Society" with like-minded people as part of the struggle of the Czech nation for liberation from its occupiers (Reguli, 2009). Two years later (1864) at the proposal of Professor Emanuel Toner the society changed its name to "Sokol" (Pavlović, Pantelić, \& Pavlović, 2017).

Received November 4, 2017 / Accepted November 1, 2018

Corresponding author: Kristina Pantelić-Babić

Faculty of Physical Education and Sports, University of Banja Luka, Bulevar vojvode P. Bojovića 1a,

Banja Luka 78000, Republic of Srpska, Bosnia and Herzegovina

Phone: +381 18510900 •E-Mail: kristina.pantelic-babic@ffvs.unibl.org 
From that day on the Sokol way of physical exercise began to spread to all countries where Slavic nations lived. In this way Sokolism arrived among the Serbs who lived on the territory of Bosnia and Herzegovina. The first attempt to establish a Serbian Soko society took place in 1893 in Foča (Babić, Pavlović, \& Živanović, 2017), but the AustroHungarian authorities did not allow it. The first Serbian gymnastic society "Obilić", approved by the Provincial Government, was established in Mostar in April 1904. Until 1910 Serbian gymnastic societies had different names: "Obilić", "Njegoš", "Dušan Silni", etc., and since 1910, when the Serbian Soko Parish of Bosnia-Herzegovina was established and approved, all previously formed societies changed their name to "Serbian Soko" (Babić \& Pavlović, 2015). Serbian Sokolism in Bosnia-Herzegovina since its establishment until the ban on its work after the assassination of the Austro-Hungarian Crown Prince Franz Ferdinand on St. Vitus Day (Vidovdan) 1914 in Sarajevo, among other things, made a significant contribution to the liberation of people of BosniaHerzegovina from the Austro-Hungarian occupation.

The main subject of this paper is Branko Čubrilović and his connection with Serbian Sokolism, and the aim is to highlight his role in the development of Serbian Sokolism, primarily in the areas of Bosnia-Herzegovina, his contribution to its development, as well as Čubrilovic's role in the development of Sokolism in other areas where Serbs lived.

In this paper the historical method was used. The Archive of the Serbian Academy of Sciences and Arts (SASA) was browsed and reviewed - a collection about Branko Čubrilović, other historical sources about him and about Serbian Sokolism incurred at the time of the relevant events, as well as sources created later.

\section{THEORETICAL CONSIDERATIONS}

\section{Short biography of Branko Čubrilović (1894 - 1962)}

Branko Čubrilović was born to Jovan Čubrilović and Savka Čubrilović (nee Lazarević) on October $28^{\text {th }}$ (old calendar) 1894 in Bosanska Gradiška. His father and mother had ten children, four daughters and six sons. Branko was born as the ninth child. He finished elementary school in his hometown and after the death of his parents he left for Tuzla in 1905 with his brother Vaso and sister Vida to live with their older brother Veljko who was working there as a teacher. In the autumn of that year, Branko enrolled in the first grade of high school (Gymnasium) (Čubrilović, n.d.). About the time that Branko, Vasa and Vida stayed with their brother Veljko Čubrilović, Veljko's wife Jovanka, among other things, wrote: "We had many financial concerns, because three people needed to be supported... Vaso had some scholarships, but I remember well how every first of the month Veljo had a headache when the bills started to arrive" (Čubrilović, 1999, p. 110).

Branko lived in Tuzla until he graduated from high school in 1913. Veljko and his wife Jovanka moved to Priboj at Majevica in early 1910 to live and work there. At the time of school breaks Branko visited his brother Veljko there. "Branko came by from time to time and always with a group of friends" (Ibid, p. 111).

Upon completion of his high school education (Gymnasium), Branko enrolled in medical school in Vienna in the 1913/14 school year. The Serbian Cultural and Educational Association SKPD "Prosvjeta" was giving scholarships to Serbian pupils and students. Čubrilović also received this scholarship of 600 crowns during his studies (Čubrilović, n.d.; 
Pavlović, 2003). In addition to Branko Čubrilović, Vukašin Babunović was also among those to receive a scholarship from the SKPD "Prosvjeta", as was Djordjo Ostojić, who also studied medicine. Besides the scholarship of SKPD "Prosvjeta", Čubrilović also received a scholarship of 300 crowns from the municipality of Bosanska Gradiška and from his brother Veljko (Čubrilović, n.d.). After the first semester, he moved to Graz in 1914, where he continued his medical studies.

After the assassination on June $28^{\text {th }}, 1914$ in Sarajevo, Branko Čubrilović was arrested in Bosanska Gradiška, where he was spending his student break, and was taken to Sarajevo. He was convicted of high-treason in Banja Luka and was sentenced to 14 years in prison. (Veleizdajnički proces 1915-1916, n.d.; Antonić, 1999)

About the sporting qualities of Branko Čubrilović, Zdravko Antonić, among other things, wrote that he was "... a brave and excellent athlete in several disciplines" (Antonić, 1999, p. 55) and that he participated "... in a number of competitions in Tuzla, Priboj on Majevica, Prague at the Prague Soko Slet in 1912, and that his stunt leaps from the bridge in Sana and Una rivers were remembered for a long time" (Ibid). Furthermore, Antonić wrote that he was "... an immediate, open, persistent, ready for great sacrifices for the sake of general things" (Ibid, p. 345), that the trajectory of his path was great, from Tuzla via Serbia, Vienna, Graz, Zagreb to Banja Luka and that the fields of his interests and work were mostly Sokolism, secret and public pupil and student organizations.

After World War I and his released from prison, Čubrilović continued and completed his medical studies in Prague and after that was employed in Banja Luka. He was a member of the parliament of the former government (the Kingdom of SCS, from 1929: The Kingdom of Yugoslavia) and twice a Minister of Agriculture.

Branko Čubrilović passed away in 1962 in Belgrade where he was buried at the New Cemetery (Novo Groblje).

\section{Participation of Branko Čubrilović in the work of student and other societies and organizations}

After the proclamation of annexation of Bosnia-Herzegovina to the Austro-Hungarian Empire in 1908, students of the Tuzla high school organized protests in which, among others, Branko Čubrilović participated. Then the Serbian students founded a society called "Booklet" ("Knjižica" in Serbian). In the fall of 1909 the society's management was elected, with Djuro Ostojić as their President. Besides Branko Čubrilović, who at the time was in his fifth year of studies in high school, the following people were accepted as members: Todor Ilić, Krsto Marić, Mitar Sofrenić, Mladen Stojanović, Nikifor Tadić, Ljubo Todorović and Stevan Hakman, who soon became the Serbian Sokols. At the insistence of the Serbian soko, doctor Risto Jeremić, who worked in Tuzla and remained "...recorded in history as a kind of Student patron and one of the initiators of the 'Serbian Soko" (Ibid, p. 57), the management of the "Booklet" addressed significant attention to the fight against alcoholism, holding lectures not only in Tuzla, but also in other areas of northern and eastern Bosnia: Bijeljina, Žabari, Modriča, Šamac and others.

Besides the "Booklet", Serbian students founded some other legal and illegal societies in Tuzla, such as: the "Literary Troop" ("Literarna družina" in Serbian), "Society of Sobriety" ("Udruženje trezvenosti" in Serbian), "School Soko Troop" ("Đačka Sokolska Družina" in Serbian), "National Defense" ("Narodna Odbrana" in Serbian) and others. 
The Secret Students' Soko Society in Tuzla was founded in 1912, whose President was Mirko Ilić, his deputy and the Head Branko Čubrilović, and Treasurer Petar Guteša.

After arriving in Vienna and Graz to study, Čubrilović also took part in the work of local Serbian societies. In Vienna in the autumn of 1913 he met Serbian soko Vukasin Babunović, who was also a student of medicine, which is when Čubrilović became a member of the club "Rad". After moving to Graz in 1914 for the second semester, he enrolled the local society called "Srbadija".

In addition to the above-mentioned organizations Čubrilović was also a member of the "National Defense" ("Narodne Odbrane" in Serbian) from Belgrade and its trustee for Bosanska Gradiška. He was recommended to Kosta Todorović for this organization by Radivoje Đuranović, a soko and member of the "National Defense" (Beatović \& Milanović, 1989). Regarding this, in the confiscated documents (log book, treasury books, reference protocol and other documents) of Kosta Todorović, 58 names of trustees of "National Defense" were found, mainly Serbian sokols. Under number 7 the name of Branko Čubrilović was recorded, the trustee for Bosanska Gradiška (Tomašević, 2011).

Čubrilović, just like the other trustees, gave lectures to spread the ideology of "National Defense" and to raise national awareness of the Serbian nation.

\section{Čubrilović's contribution to the development of Serbian Sokolism}

According to the writing of Veljko Čubrilović's wife, Jovanka Čubrilović, after his arrival in Priboj on Majevica at the beginning of 1910, Veljko founded several Serbian societies in that place: "Serbian Soko", "Brotherhood" ("Pobratimstvo" in Serbian), the subcommittee of SKPD "Prosvjeta" and "National Reading-room". During the same year he also organized a Soko gathering (Slet) in which sokols from Brčko, Zvornik and Tuzla also participated (Čubrilović, 1999).

When staying with his brother Veljko in Priboj during school breaks in 1910 and 1911, Branko got familiar with Sokolism and soon became a member. He read Soko journals "Serbian Soko", "Serbian Soko Herald", "Knight" ("Vitez" in Serbian), as well as articles on Sokolism published in the newspaper "Serbian Word" ("Srpska Riječ" in Serbian).

Branko Čubrilović was "... a member and leader of a secret student soko organization in Tuzla" (Veleizdajnički proces 1915-1916, n.d., p. 248; Antonić, 1999, p. 312) and during that time he "... was working on spreading Sokolism and sobriety" (Antonić, 1999, p. 312). After establishing the Serbian Soko society in Modriča in 1911, Čubrilović received 30 crowns from Mihajlo Jovanović for the work of that Student Soko Society (Čubrilović, n.d.).

During the 1911/12 school year, when Branko Čubrilović was a student of the seventh grade of high school, the students founded "... their secret literary society" (Antonić, 1999, p. 312) whose president was Petar Guteša. As a part of the Society there were various committees and sections for work with youth: the Committee for Sokolism and Brotherhood, a Section for analphabet courses and Sections of peasant cooperatives. Čubrilović was a member of the Board for Sokolism and Brotherhood, along with Todor Ilić and Vojislav Vasiljević.

During the school break in summer of 1912, Branko Čubrilović and Vojislav Vasiljević went to various places in northern and eastern Bosnia to give lectures, the first one about Sokolism and the second one about Brotherhood. That year they founded the Serbian Soko Society and the Brotherhood in Kožuhe, whose members trained under Jovan Perenčević. 
They founded both of these societies in Koprivna as well. Vasiljević stayed in Koprivna to organize the exercises of Sokols and Brothers, and Čubrilović went to Modriča to visit the Serbian Soko Society founded during 1911 (Čubrilović, n.d.).

Branko Čubrilović was in constant contact with Serbian sokols: Petar Guteša, Todor Ilić, Mihajlo Jovanović, Božidar Tomić and others, who founded Serbian Soko societies in other places. Božidar Tomić in 1912 founded the Serbian Soko Society in Srebrenica, Petar Guteša spread the Soko idea in place Vranjak and Todor Ilić exercised with sokols in Boljanić (Veleizdajnički proces 1915-1916, n.d.).

Čubrilovic participated as a contestant on the All-Slovenian Sokol Slet in Prague in 1912, which was deeply etched into his soul and strengthened his loyalty to his Slavic brothers. He noted that one of the Austro-Hungarian Journals wrote that “... this AllSlovenian Slet without any sound or color knocked over imperial Vienna and that the days are numbered for Pest too" (Čubrilović, n.d., p. 32). After returning from Prague Čubrilović in a letter dated August $20^{\text {th }}, 1912$, among other things, wrote “... that he straight from Prague went to the villages Hrge, to Vozuća, Travnik, Bugojno, Livno, Koprivna, Vranjak, Konjuhe, Žepče, Maglaj" (Antonić, 1999, p. 314) to spread the Soko idea and to establish Serbian Soko societies.

Čubrilović travelled to Serbia for the first time in 1913. In Belgrade he met Milan Šarić who informed him that his sister doctor Staka Bokonjić had gone to Kragujevac. He went to his sister, and there he spent time with Serbian Sokols, doctors Risto Jeremić and Jovo Bokonjić (his brother in law), who worked in the hospital in Kragujevac. In his records from a trip across Serbia Branko Čubrilović, among other things, wrote about sokols and Sokolism that: "Sokols have the sacred duty of national awakening" (Ibid) and will give to Serbian Sokolism “... a conscious man and a Serb in every aspect, who will be able to be here and there and survive everywhere" (Ibid).

About Sokols and Brothers he said as follows: "Not to multiply both of them (Sokols and Brothers) means not to succeed completely with either idea" (Ibid). He compared sokols "... to gusle ${ }^{2}$, which used to raise heroes, because the hour is approaching, the time of big events is coming, where skills and heroism will be needed, self-sacrifice and soundness" (Ibid). He further wrote that "Sokolism instills in a member the courage to expose himself to danger for the national and the right thing" (Ibid), that Serbian sokols are "... the inheritors of our heroes" (Ibid), that they should be "... educated to be able to always exchange their red shirts for ones painted with blood" (Ibid), that "... Sokolism contains repugnance towards the tyrant, the yearning for freedom and it expands them by example, not by moralizing" (Ibid). But this program could not "... officially be entered in our policies, it was concealed by a naive program, gymnastic society" (Ibid). In order to succeed with this "... sanative idea (Soko idea) to the point, to not just say: 'Serbian Soko is mighty, glorious` but 'the Serbian nation is mighty and glorious" (Ibid). Regarding Sokolism he said that it was a "... convenient institutions, which must take more national, revolutionary, fighting, resistant character so that in a certain moment our numbers could be used for the opus of our national idea" (Ibid). Regarding the question of the investigators involved in his trial for high-treason trial in Banja Luka, which was the purpose of that trip to Serbia, Čubrilović answered: “... that he only performed his duties as the one who always said the following in the soko gym: 'Sokols will, mother (Serbia), give their life for you"' (Ibid).

\footnotetext{
1 “... stići i uteći i na strašnom mestu postojati.” - Phrase from Serbian epic poetry (free translation of author).

${ }^{2}$ Gusle - a kind of national bowed string instrument.
} 
In the spring of 1914 Čubrilović in Tuzla in the Serbian Sokol Gym lectured Serbian sokols and other Serbian youth about the necessity of accepting Yugoslav ideology. At his insistence at that moment the Yugoslav program of the organization "National Unification" ("Narodno Ujedinjenje" in Serbian) was accepted, which enrolled about 40 youngsters, mostly sokols: Stevan Botić, Alojzije Budimir, Jezdimir Dangić, Todor Ilić Mladen Stojanović, Božidar Tomić and others. The management of the organization consisted of Serbian sokols: President Todor Ilić, Vice president Mladen Stojanović, Secretary Božidar Tomić and Treasurer Vojislav Vasiljević.

During the High-treason trial in Banja Luka Branko Čubrilović, among other things, said about the Soko idea that it was "... the idea of revolution and that he loved it", (Veleizdajnički proces 1915-1916, n.d., p. 250) that “... the Soko idea matches up with the revolutionary one" (Ibid) and that he propagated it "... to achieve the revolutionary one", (Ibid; Antonić, 1999, p. 316) that Sokolism “... does not tolerate slavery and wants freedom, ...therefore Sokolism will nurture our tribe for the sacrifices required for success." (Veleizdajnički proces 1915-1916, n.d., p. 249). During Čubrilović's trial, the court came "... to a complete conviction that the accused perceived sokol thought, the national thought, the sokol task as interpreted in the soko literature, and as we see in the brochure of 'National Defence', and therefore acted in this direction” (Ibid).

\section{Correspondence and cooperation with sokols}

Čubrilović was in contact with a number of sokols and members of other Serbian societies and organizations (Vukašin Babunović, Petar Guteša, Radivoje Đuranović, Stevan Žakula, Doctor Risto Jeremić, Mihajlo Jovanović, Đuro Ostojić and others), corresponded and cooperated with them, all in order to achieve the set Sokol objectives for the benefit of his nation.

In a letter dated November $8^{\text {th }}, 1913$ to Serbian soko Todor Ilić, with whom he was in constant contact, Čubrilović, among other things, wrote: "Do not change your good opinion about me, and I think, you'd be convinced in the near future. I'm waiting for new generations, with whom I will work, and by that I was thinking about the people from Tuzla.” (Ibid, p. 250). He also wrote him about "... the common national work and he claims, that all Serbian Youth from: Vienna, Prague and Graz are united into one club of national team workers, and their setup will be based on the one from our high school" (Ibid, p. 81).

For certain Serbian sokols, defendants in the High-treason trial in Banja Luka, among other things, an aggravating circumstance was their acquaintance with Branko Čubrilović. He was in contact with soko Ljubomir Mijatović, who was considered an outstanding Soko worker. For Mijatović, among other things, the indictment read: "Branko Čubrilović calls him the famous soko worker" (Ibid, p. 269). For Petar Božić, the founder of the Serbian Soko society in Puračić in 1911, an aggravating circumstance in the trial was also the fact that he knew Branko Čubrilović. "He knows Branko Čubrilović, a year before he founded Soko in Puračiću, he attended a party regarding St. Sava day" (Ibid, p. 278).

Čubrilovic was also in constant contact with soko Vukašin Babunović, who also studied medicine at the University of Vienna. While Čubrilović was in Vienna, they lived in the same house. His acquaintance with Čubrilović was considered an aggravating factor for Babunović in the High-treason trial in Banja Luka. In a letter to Vukašin Babunović, from January $2^{\text {nd }}, 1914$, Cubrilovic, among other things, wrote about the revolution and 
said that it "... embraces people of freedom, hurt and depressed souls, and from which no one expects anything. All Serbian movements are based indirectly on revolution." (Ibid, pp. 249-250; Antonić, 1999, p. 315).

In the indictment for Vukasin Babunović, among other things, was:

"He discussed with Branko Čubrilović n a t i o n a 1 w o r. By this he implied the establishment of societies: Soko, Sobriety, work regarding the Prosvjeta and literacy courses, but otherwise he namely disagreed with excessive control on the part of Branko $\check{\mathrm{C}}$ u b r i 1 o v i ć. His controls and letters are opposed to this.

From all the things stated so far in regards to the first part of these reasons, based on the defendant's hostility against the Monarchy, from his correspondence with Branko Čubrilović, from the letter to Petar Božić (writes about Soko idea), from his acquaintance and negotiating with him about Sokolism, the court comes to the conclusion that the defendant was fully versed in high-treason tasks of Serbian Sokolism and 'National Defense', and therefore in the intention stated under A. in tenor of this judgment in both oral and written correspondence with Branko Čubrilović and Petar Božić encouraged them, to vivaciously and consciously work on establishing of Serbian Soko societies and thus also promoted the political unity of the Serbian people" (Veleizdajnički proces 1915-1916, n.d., p. 280).

After the verdict (on April 22 $2^{\text {nd }}, 1916$ in Banja Luka) to 14 years in prison, on April $25^{\text {th }}$ the same year, Branko Cubrilović's two-and-a-half-year-old nephew Nada (the daughter of his assassinated brother Veljko Čubrilović) accompanied by her aunt Jelenka (Veljko's sister) visited Branko in the "Black House" prison in Banja Luka. Before and after the visits, he wrote a letter to Jovanka Čubrilović, the wife of his assassinated brother Veljko. In this letter, among other things, he states:

"I got 14 years ... Besides Soko revolutionary activities, as the court calls it, I am punished also as a member of the 'National Defense'. We didn't change. We all know that our destiny is tied up with the fate of our nation. It will live forever - because it is able to live. We believe in its future and complex life. This will save us too... We will see in two years at the most. I believe strongly in victory if God is up there - I believe a lot in the strength of our tribe, and our salvation” (Pismo Branka Čubrilovića....., 1999, pp. 322).

\section{Branko Čubrilović on High-treason trial in Banja Luka}

At the end of the indictment the Court noted that Branko Čubrilović in

“... correspondence with Radivoje Đuranović, then in the secret student organization, and by coming into contact with excellent factors of Sokolism during the Prague slet, learned about the purpose of 'National Defense' and task of Sokolism in achieving its high-treason ideas, and besides all that he spread Sokolism and Brotherhood and participated with word and deed in the intention stated under A. Accordingly the Court is convinced of his guilt, and concluded: that he joined the organization of the Serb. revolutionary society 'National Defense in Belgrade as a member, knowing that the society's goal and task is as listed under A. in tenor of the conviction, that in this high-treason work he is involved by founding Soko societies and by systematic revolutionary work in them, whose main purpose was to support under A. in tenor of conviction marked 
high-treason goal of 'National Defense', and he knew that in a similar society in Serbia they were congregating in the chivalrous section of 'National Defense'.

The defendant's action contains all the elements of crimes under $\S 111$, so the court found him guilty of this transgression" (Veleizdajnički proces 1915-1916, n.d., p. 250).

Letter B. included eight convicts, amongst them also Branko Čubrilović. "Branko Čubrilović, son of the late Jova, born in and recently a resident of Bos. Gradiška, SerboOrthodox religion, born on October $28^{\text {th }}, 1894$ of the old calendar, a student of medicine, single, viceless" (Ibid, p. 6; Antonić, 1999, p. 304). Further, it says that they are guilty

“... for the intention marked under A. in the period from 1911 to 1914 joined the above-mentioned revolutionary organization 'National Defense' as trustees or members knowing the above highlighted task and objective of that organization, and participated in the same, as follows: 2. Branko Čubrilović, by founding Serbian Soko society knowing the prominent high-treason goal of these societies, and by systematic revolutionary work in them" (Veleizdajnički proces 1915-1916, n.d., p. 6).

Thereby committing the "... crime of treason from $111 \mathrm{~b} \mathrm{cl"} \mathrm{(Ibid,} \mathrm{p.} \mathrm{12)} \mathrm{and} \mathrm{are}$ sentenced "... according to $\S 112$ b/2 cl. each to 14 years" (Ibid., p. 13; Beatović \& Milanović, 1989, p. 218). The verdict was rendered on April 22 ${ }^{\text {nd }}$, Easter Saturday 1916.

\section{CONCLUSION}

Based on the aforementioned, we can conclude that Branko Čubrilović during his high school days in Tuzla was involved in the work of the Soko School and other Serbian societies. Staying with his brother Veljko Čubrilović during school breaks, Branko participated in the founding of Serbian Soko societies, their work, as well as in the spreading of Soko ideas. He continued with these activities during his medical studies in Austria (in Vienna in 1913 and Graz in 1914). In this way, Branko Čubrilović made a significant contribution to the development of Serbian Sokolism in the areas of BosniaHerzegovina until the beginning of the World War I, as well as in other places where he was staying. Among other things, due to involvement in Sokolism, after the assassination of the Austro-Hungarian Crown Prince Franz Ferdinand on June $28^{\text {th }}, 1914$ in Sarajevo, he was arrested and taken to Sarajevo. After the arrest, during the High-treason trial in Banja Luka in 1916 he was sentenced to 14 years of hard labor. After World War I ended, he was released from prison. After being released, he continued and completed his medical studies in Prague, after which he was employed in Banja Luka. Besides his professional engagement, he continued his involvement in Sokolism.

\section{REFERENCES}

Antonić, Z. (1999). Čubrilovići 1914. i kasnije (Čubrilović family in 1914 and later). Belgrade: Serbian Academy of Sciences and Arts (SASA), Institute for Balkan Studies SASA. In Serbian

Babić, K., \& Pavlović, P. D. (2015). Učešće Čedomira Milića u radu sokolskih organa (The participation of Čedomir Milić in the work of Sokol authorities). In: I. Parčina (Ed.), Proceedings of the 10th International 
Scientific Conference "Challenges in Contemporary Sport Management", (pp. 242-248), Alfa University: Faculty of Sport Management. In Serbian

Babić, K., Pavlović, P. D., \& Živanović, N. (2017). Beginnings of Serbian Sokolism in Herzegovina. Physical Education and Sport Through the Centuries, 4(2), 57-75

Beatović, Đ., \& Milanović, D. (1989). Veleizdajnički procesi Srbima u Austro-Ugarskoj (High-treason trials to Serbs in Austro-Hungary). Belgrade: NIRO Književne novine. In Serbian

Čubrilović, B. (n.d.). Politički zapisi i moja sećanja, prvi deo, Rođenje, mladost, đački i studentski život od 1905-1921, ljekarski poziv $i$ dolazak u Sarajevo 1921 (Political records and my memories, part one, Birth, youth, school and student life from 1905-1921, medical profession and arrival to Sarajevo in 1921). SASA, 14449/IV. In Serbian

Čubrilović, J. (1999). Zapis iz 1965. godine (Record from 1965). In Z. Antonić (Ed.). Čubrilovići 1914. $i$ kasnije (Čubrilović family in 1914 and later). Belgrade: Serbian Academy of Sciences and Arts (SASA), Institute for Balkan Studies. In Serbian

Pavlović, D.P. (2003). „Prosvjeta“ i sokoli („Prosvjeta“ and sokols). In R. Bratić (Ed.), Congress proceedings, Sto godina „Prosvjete“ $i$ njenih znamenitih ličnosti, Ćorovićevi susreti 2003 (One hundred years' of "Education” and its famous personalities, Corovic Encountings 2003). , (pp. 561 - 577). Belgrade: Fond „Svetozar \& Vladimir Ćorović“, Bileća-Gacko: SPKD „Prosvjeta“. In Serbian

Pavlović, P., Pantelic, B.K., \& Pavlović, D. (2017). "Serbian Sokol” in Barberton (Ohio). Gymnasium, 16(2).

Čubrilović, J. (1999). Pismo Branka Čubrilovića Jovanki Čubrilović od 25. aprila 1916. godine, „Crna kuća“, Banja Luka (Letter of Branko Čubrilović to Jovanka Čubrilović from April $25^{\text {th }} 1916$, „Black House“, Banja Luka). In: Z. Antonić, Čubrilovići 1914. i kasnije (Cubrilović family in 1914 and later) (pp. 319 322). Belgrade: Serbian Academy of Sciences and Arts, Institute for Balkan Studies SASA. In Serbian

Reguli, Z. (2009). Taxonomy of combatives as it is seen from Tyrš tradition in the Czech Republic. Ido Mov Cult, 9, 38-43.

Tomašević, M. (2011). Banjalučki veleizdajnički proces (Banja Luka high-treason trial). Banja Luka: Besjeda / Gimnazija Banja Luka. In Serbian

Veleizdajnicki proces 1915-1916 (High-treason trial 1915-1916) (n.d.). Banja Luka: Archive of the Museum of Republic of Srpska, Provincial Pressroom. In Serbian

\section{BRANKO ČUBRILOVIĆ I SRPSKO SOKOLSTVO}

Krajem 19. veka u Češkoj se pojavio novi način telesnog vežbanja, koji je dobio naziv "Sokolski" ili "Tiršov" system. On se proširio na sve zemlje gde su živeli Slaveni i na taj način stigao i među Srbe koji su živeli na prostorima tadašnje Hercegovine i Bosne. Grupa Srba je u Foči 1893. godine pokušala da osnuje srpsko sokolsko društvo ali im okupatorska austrougarska vlast to nije dozvolila. Prvo srpsko gimnastičko društvo na prostorima Hercegovine i Bosne pod nazivom „Obilić“ osnovano je u Mostaru 1904. godine. Mnogi učeni ljudi toga vremena učestvovali su u radu sokolskih organizacija, a među njima se nalazio i dr Branko Čubrilović. Predmet rada je dr Branko Čubrilović $i$ njegova povezanost sa srpskim sokolstvom, a cilj da se osvetli njegova uloga u razvoju srpskog sokolstva, pre svega na prostorima Hercegovine i Bosne, kao i na drugim prostorima gde su živeli Srbi. U radu je korišćen istorijski metod. ljučne reči: sokolska društva, sokoli, đaci, član.

Ključne reči: sokolska društva, sokolci, studenti, članovi 